\title{
Dumbbell-like organisms of marine ecotopes in the coastal waters of the Sevastopol region
}

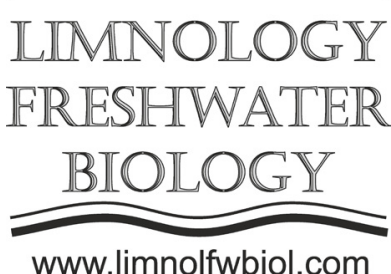

\author{
Andreeva N.A. \\ Institute of Natural and Technical Systems, Russian Federation, Sevastopol, Lenin St., 28 299011, Russia
}

\begin{abstract}
The results are presented of the long-term studies of phytoplankton, periphyton, benthos samples and the scrapings from dolphin skin during a prolonged cultivation utilizing the modified Gromov’s №6 media. In some cases, under a microscope in the obtained cultures unusual organisms were detected, which were observed as dumbbell shaped, silvery olive color and comparable size to some microalgae forms. It was noted that depending on the habitat and incubation duration on the media, they varied in size and their developmental extend. It is not possible currently to obtain a pure culture, and the taxonomic affiliation of these microorganisms is also unknown.
\end{abstract}

Keywords: dumbbell-like organisms, Gromov’s №6 media, coastal marine water area, the Sevastopol region

\section{Introduction}

Marine micro-organisms are an important component of marine ecosystems. They make up about $70 \%$ of the ocean biomass. This group includes organisms such as viruses, prokaryotes (bacteria, archea and cyanobacteria), as well as various microscopic eukaryotes (microalgae, protozoa, etc.). Microorganisms play an extremely important role in various water reservoirs, due to the fact that they perform closed cycles of the main nutrient elements $(C$, $\mathrm{N}, \mathrm{P}, \mathrm{S}, \mathrm{Fe}$, etc.). The diversity of these water organisms is rather great, but, nevertheless, their study is severely lacking. More extensive research of various marine ecotones will allow the discovery and study of new forms that can assist in understanding global processes occurring in marine ecosystems (Dang et al., 2019).

The objective of this study is a research and preliminary examination of the new, for the Black Sea region, dumbbell - shaped organisms, which were discovered in various ecotopes of the marine water area of the Sevastopol coast.

\section{Material and methods}

The research was conducted during 20092019 at several stations in the coastal area. Samples of phytoplankton, periphyton, benthic and scrapings from dolphin skin were studied. Plating was carried out in test tubes with $10 \mathrm{ml}$ of Gromov No. 6 liquid modified media (on seawater): $1 \mathrm{ml}$ of water sample, $0.5 \mathrm{~g}$ of biofouling, $1 \mathrm{~g}$ of the bottom sediments, or the dolphin epidermis scraping within a zone of $100 \mathrm{c} \mathrm{m} 2$. The sample incubation was performed during 30-120 days or longer under natural or artificial light and in a luminating stand at ambient temperature.

Live specimens were examined using the light biological microscope Levenhuk 740T, set at magnification $x$ 400. Photographing of the cultures was performed using a digital attachment with the Levenhuk ToupView computer program and further processing of images in Adobe Photoshop CS3, Extended.

\section{Results and Discussion}

As long-term studies indicated, during cultivation on the Gromov's No. 6 nutrient media (for algae and cyanobacteria) in some samples, after a month of incubation, dumbbell-shaped silver-olive color microorganisms, comparable in size to some microalgae, were detected under light microscoping.

The first time similar organisms were identified by us in 2007 in marine bottom sediments contaminated with reduced sulfur compounds (Smirnova and Andreeva, 2009) utilizing Van Nil's media (a media used for phototrophic bacteria) after a 3 month incubation period in the light. Previously, it has been stated (Sergeev, 1993; Rozanov, 2002), that the dumbbellshaped organisms were detected in Precambrian deposits. No other information about such organisms were found in either national or foreign literature. According to measurements, the cells dimensions were 4.4-8.0 $\times 19.3-22.5$ microns on average, and the width of the band was 2.3-2.8 microns.

At this stage, it is not possible to receive algological pure cultures, as the organisms do not grow on a solid media. The dumbbell-shaped organisms,

*Corresponding author.

E-mail address: andreeva.54@list.ru (N.A. Andreeva)

(C) Author(s) 2020. This work is distributed under the Creative Commons Attribution 4.0 License. 


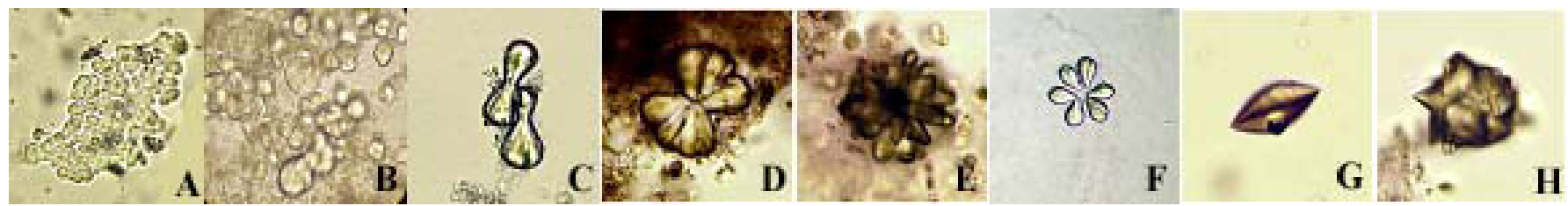

Fig. 1. Stages of dumbbell-shaped organisms' development

while cultivated in test tubes, were presented only in bottom sediments layers. In order to support the viability of these organisms, a portion of the cultural fluid, containing metabolic products, was removed from the culture time to time and fresh nutrient media was added. Additionally, periodical microscopic examinations of the samples were conducted. During long-term observation, various stages of dumbbellshaped organisms' development were identified (Fig. 1).

Presumably, at the initial stage of development, the organisms have the form of a microscopic "lichen" (Fig. 1A), the individual elements of which were then differentiated into rounded plates (Fig. 1B), which later formed dumbbell-shaped cells (Fig. 1C). The cells also were able to divide both in longitudinal and in transverse direction (Fig. 1D, Fig. 1E, Fig. 1F). In the case of multiple divisions occurrences, micro-colonies were formed in a "flower" shape. These micro-colonies either disintegrated into separate dumbbell-shaped cells or merged into rounded configuration conglomerates (Fig. 1H), which together formed crystal-like structures. Concurrently, individual lancet-shaped cells were observed in the culture (Fig. 1G). From both of them, dumbbell-shaped forms could also be differentiated. It should be noted that dumbbell-shaped cells in different samples and at different stages of development could have a size 2 times larger or smaller than their average parameters indicated above.

\section{Conclusions}

According to a number of characteristics, these organisms were presumably assigned to Cyanobacteria. We observed that they grew well on the Gromov's No. 6 media and, depending on the habitat and incubation duration on the media, they varied in size and development stage (Andreeva et al., 2012). However, in order to accurately determine their systematic affiliation, electronic microscopic and genetic examinations are necessary to be conducted. It is possible that dumbbell-shaped organisms are a new, previously unknown taxon of marine microorganisms.

\section{Acknowledgments}

The author expresses her sincere gratitude to the management of the Institute of Natural and Technical Systems for the opportunity to carry out these studies

\section{References}

Andreeva N.A., Ostapchuk N.V., Liskun O.V. 2012 Bacterio - and phytoplankton of coastal enclosures with dolphins (Kazachya Bay). Ekosistemy, ikh Optimizatsiya i Okhrana [Ecosystems, their optimization and protection] 6: 20-30. (in Russian)

Dang H., Klotz M.G., Lovell C.R. et al. 2019. The responses of marine microorganisms, communities and ecofunctions to environmental gradients. Frontiers in Microbiology 10. DOI: 10.3389/fmicb.2019.00115

Sergeev V.N. 1993. Cyanobacterial communities at the early stages of biosphere evolution. In: Rozanov Yu.A. (Ed.), Problemy doantropogennoy evolyutsii biosfery [Problems of pre-anthropogenic evolution of the biosphere]. Moscow, pp. 254-265. (in Russian)

Smirnova L.L., Andreeva N.A. 2009. Unusual dumbbellshaped microorganisms from marine sediments contaminated with reduced sulfur compounds. Ekologiya Morya [Marine Ecology] 79: 79. (in Russian)

Rozanov A.Yu. 2002. Fossil bacteria, sedimentation and ore formation. In: Bakterial'naya paleontologiya [Bacterial paleontology]. Moscow, pp. 107-113. (in Russian) 